\title{
Technology of Tofu Pressing Tool With Time Delay Valve Pneumatic System
}

\author{
Mila Kartika*, Milati Febriyani, Muhamad Ilyas Wijaya, Purnawan \\ Pendidikan Teknik Mesin, Fakultas Pendidikan Teknologi dan Kejuruan \\ Universitas Pendidikan Indonesia \\ Bandung, Indonesia \\ *milakartika@upi.edu, milatifebriyani@upi.edu,377ysx@upi.edu, purnawan@upi.edu
}

\begin{abstract}
The survey results in several tofu industries in West Java, on average, still use manual tools. The process of making traditional tofu takes a long time to press, so it requires new technology, a tool that is easier to use and does not take a long time. Technology of tofu pressing tool with time delay valve pneumatic system is here to solve this problem. This tool is an automatic pressing device designed to replace the manual press. This time delay valve system also has the advantage of being able to work automatically by itself, thereby reducing work and time spent more efficiently. The purpose of this activity was to produce a tofu pressing device technology design with a time delay valve pneumatic system for optimization of the production process. The method used in this study was Desain And Development. The stages taken are identification of the problem, describing the objectives, product design and development, product testing and evaluation of trial results, communicating the test results. Data collection techniques are observation and documentation study. The design and testing process used Inventor and Fluid SIM-P 4.0 software. This research has resulted in designs of pneumatic cylinders, pressure plates, tofu product storage containers, tool frames, and compressors. The test results show that the tofu pressing device with a time delay valve pneumatic system can increase the productivity of tofu making in the home tofu industry.
\end{abstract}

Keywords-pressing, pneumatic, simulation, tofu, time delay valve

\section{INTRODUCTION}

Tofu industry is a home industry that usually still uses traditional tools in its processing. This led to the idea of improving the tofu processing process to help the tofu industry in Indonesia, especially in Bandung, West Java, where there are 250 active tofu craftsmen [1]. The tools used for the tofu making process are still manual. Only in mills that use machines. In the pressing process, the tools used are still classified as traditional, namely in the form of stones that are lifted manually by employees weighing $10-15 \mathrm{~kg}$. The process of using stone as a pressing tool in addition to causing a long pressing time, which is not less than 30 minutes. Asih [2] also results in uneven tofu surface. The results of the observation found that there was a tofu press device, but the process was still manual without being equipped with a pressing timer. Although the surface can be flatter than using stone, the production capacity is still only $12 \mathrm{~kg} /$ hour.

Based on the exposure to the problems of the tofu pressing process, the PKM team designed a tofu pressing device with a pneumatic time delay valve system to make it easier and easier for workers in tofu production because it has a function to delay air flow until a predetermined time. This time delay valve system also has the advantage that it does not have to wait for the pressing time because there is time to make it work itself.

Based on this, the PKM Team decided to carry out an activity entitled "Technology of Tofu Pres sing Tool with Time Delay Valve Pneumatic System". The formulation of the problem is, How to design an automatic tofu press that is reliable, practical and at an economical price?

In general, this activity aims to produce a design for Tofu Pressing Tool Technology with Time Delay Valve Pneumatic System. Based on the formulation of the problem posed, the specific objectives of this activity are as follows: (1) Produce mechanical designs, including designs for tables, boxes, cylinders, cylinder holders, pressing plates, wastewater collection boxes, tool frames. (2) Producing a control system design for Tofu Tool Technology with Time Delay Valve Pneumatic System. (3) Produce estimated production costs/ unit costs, estimated machine operating costs, and estimated profit projections from the implementation of Tofu Pressing Tool Technology with Time Delay Valve Pneumatic System.

This research is expected to provide practical benefits for home producers and workers in the process of making tofu, which is to save time and can increase the number of tofu products that are quite large, which can be trusted by many people because it is more sterile, and benefits for workers as well so that workers do not to heavy at work.

\section{LITERATURE REVIEW}

\section{A. Tofu Making Process}

Tofu is a traditional food made from soybeans, which are rich in protein and low in sodium, cholesterol and calories. 
Because the effects of soybeans are good for health, tofu is considered a healthy food which, if consumed, can be beneficial for health [3]. The process of making tofu begins with selecting the quality of soybeans, namely by choosing large seeds, then washing them with clean water and then soaking in plenty of water for six hours. The next process is washing, stripping, crushing, until it becomes good soybean pulp. Next is the provision of thickening, compaction, and cutting agents [4].

\section{B. Pneumatic System}

In the process of designing the Technology of Tofu Pressing Tool with Time Delay Valve Pneumatic System using a pneumatic system consisting of a compressor, time delay valve, double-acting cylinder.

A compressor is a machine or mechanical device that works to increase pressure or compress gas or air fluid. The time delay valve serves to delay the flow of air to a predetermined time. The air will first flow to the storage tube, when the new full discharge will flow to another channel. Double-acting cylinder is a cylinder that has two input and output ports This type of cylinder uses pressurized air force to push the piston out and push the piston to enter the starting position (pulling in).

\section{METHODS}

The method used in this research is Desain And Development. The stages taken are identification of the problem That we got from preliminary studies, describe the goal, product design and development yang start from draft analysis and calculation of machine elements and design of control system, And then product testing and evaluation of trial results, if product is rejected then must be repaired in calculation of machine elements and design of control system, if product is accepted then it must be final design that resulted the output. The steps for the activities carried out are shown in Figure 1.

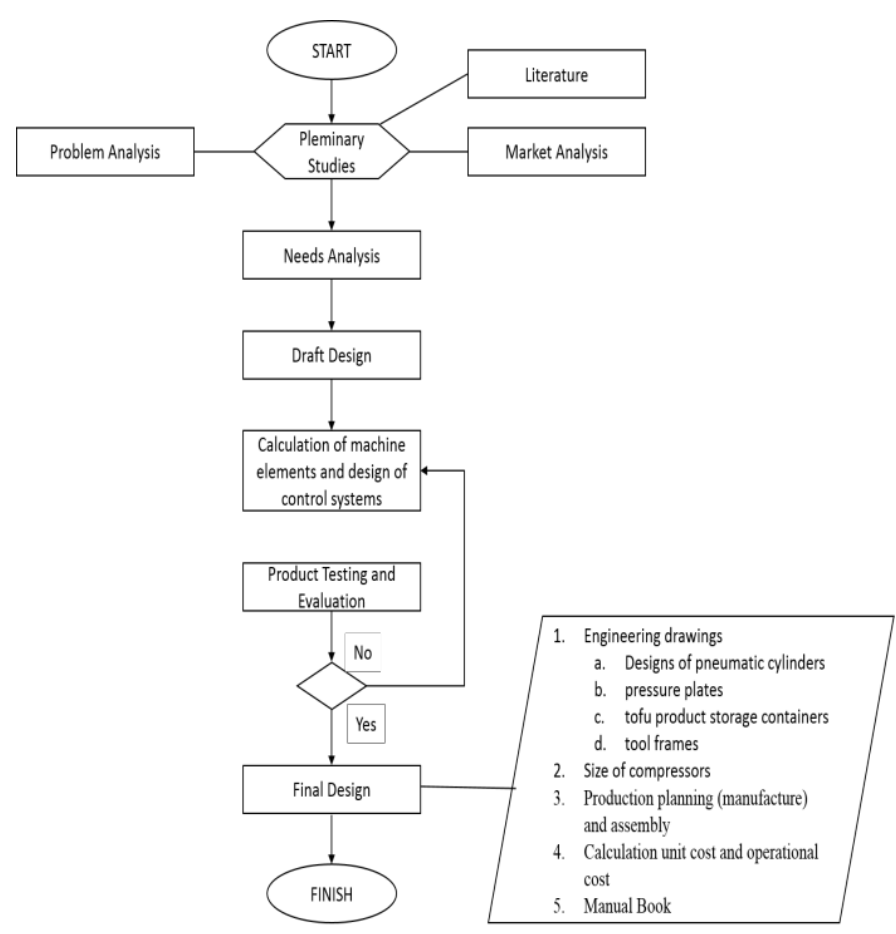

Fig. 1. Flowchart activity stages.

\section{ANALYSIS AND DISCUSSION}

\section{A. Needs Analysis}

Needs analysis is carried out to find solutions to problems found in society. This is done so that the solutions provided are effective and right on target.

\section{B. Draft Design}

In this case the machine design is still rough or still in the basic design stage, as in Figure 2 with the names of the components described in Table 1.
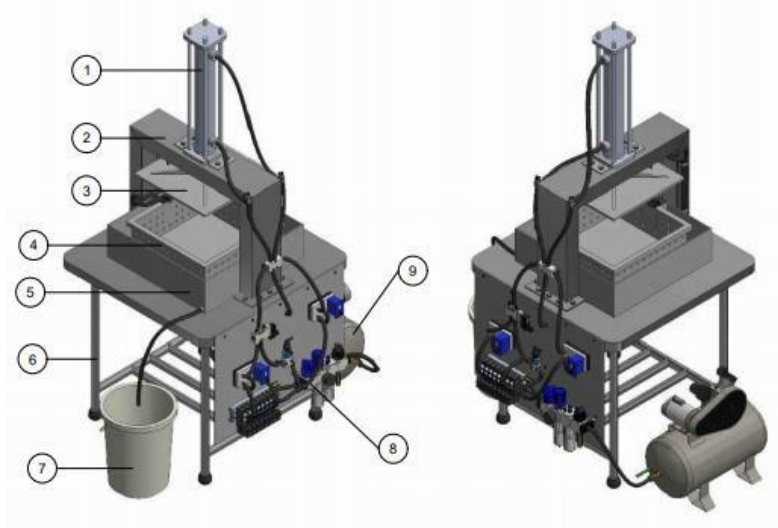

Fig. 2. Draft design. 
TABLE I. TOOLPART NAME

\begin{tabular}{|l|l|}
\hline \multicolumn{1}{|c|}{ Number } & \multicolumn{1}{c|}{ Part Name } \\
\hline 1 & Cylinder pneumatic \\
\hline 2 & Pneumatic cylinder holder frame \\
\hline 3 & Press plate \\
\hline 4 & Press box \\
\hline 5 & Water container box \\
\hline 6 & Tool Frame \\
\hline 7 & Wastewater shelter \\
\hline 8 & Pneumatic systemcomponents \\
\hline 9 & Compressor \\
\hline
\end{tabular}

\section{The Design Process for Estimated Operational Time}

It is assumed that the estimated time required in one pressing cycle for this tool is 152 seconds, then the details of the estimated design time based on the operational steps can be seen in Table 2.

TABLE II. ESTIMATED MAChine OPERATING TIME

\begin{tabular}{|l|l|l|}
\hline No. & \multicolumn{1}{|c|}{ Operational Steps } & $\begin{array}{c}\text { Estimated Time } \\
\text { (seconds) }\end{array}$ \\
\hline 1 & Enter the soybean essence into the press box & 20 \\
\hline 2 & Press theactivation button & 2 \\
\hline 3 & The pressing process & 120 \\
\hline 4 & The pressing result is transferred & 10 \\
\hline \multicolumn{2}{|l}{ Total Estimated Time } & 152 \\
\hline
\end{tabular}

\section{Machine Element Design Process}

Calculation of Machine Elements and Control Systems to determine the strength of the tool and how much it will cost or is needed to make automatic tofu presses with a time delay valve pneumatic system which is of course to make a more efficient tool that can be used by the tofu- making home industry.

1) Capacity planning:

- Number of cycles/hours. Based on the estimated operational time planning, it is known that ts $=152$ seconds $(2.53$ minutes $\approx 3$ minutes $)$ and if the pressing process is carried out within one hour (60 minutes), then the pressing process that can be done (ns) is:

$$
\begin{aligned}
& n_{g}=\frac{T p}{t s} \\
& n_{g}=\frac{60}{3}=20 \text { cycle /hour }
\end{aligned}
$$

- Previous tofu volume: $\mathrm{Vt}=96 \times 10^{5} \mathrm{~mm}^{3}$

- Final tofu volume: $\mathrm{V}_{\mathrm{h}}=48 \times 10^{5} \mathrm{~mm}^{3}$

- Final tofu weight. Based on previous data, it is known that $\mathrm{Vh}=48 \times 105 \mathrm{~mm}^{3}$ and according to Fadillah [5] that $\rho t=923.08 \mathrm{~kg} / \mathrm{m}^{3}$. Then the mass of tofu in this design is:

$$
\begin{aligned}
& M=\rho \times V h \\
& M=912,08 \mathrm{~kg} / \mathrm{m}^{3} \times 48 \times 105 \mathrm{~mm}^{3} \\
& M=4,43 \mathrm{~kg}
\end{aligned}
$$

- Pressing capacity/cycle. In this design it is estimated that the capacity of pressed tofu starch (Qo) is 0.096 $\mathrm{m}^{3} /$ hour, and the number of pressing cycles is known: $\mathrm{ns}=20$ cycles /hour. Based on these data, to produce tofu capacity of $0.096 \mathrm{~m}^{3} /$ hour is:

$$
\begin{aligned}
& Q_{\varepsilon}=\frac{Q_{0}}{n s} \\
& Q_{\varepsilon}=\frac{0,096}{20}=0,0048 \mathrm{~m}^{3} / \text { cycle }
\end{aligned}
$$

- Pressing capacity

$$
\begin{aligned}
\text { Qh } & =\text { Vh } \times \mathrm{ns} \\
\text { Qh } & =48 \times 105 \times 20 \\
& =96.000 .000 \mathrm{~mm}^{3} / \text { hour } \\
& =0,093 \mathrm{~m}^{3} / \mathrm{hour}
\end{aligned}
$$

- The total pressing force

$$
\begin{aligned}
& F_{\mathrm{t}}=147 \mathrm{~N} \\
& F_{p}=\frac{F_{\mathrm{t}}}{R}=\frac{147}{0,9}=163,3 \mathrm{~N}
\end{aligned}
$$

2) Calculation of machine framework:

- Press box planning It is planned that the press box material is made of ST 37 steel. According to Arora [6], this type of steel has the following stress characteristics:

$$
\begin{array}{ll}
\text { Yield Stress }(\sigma \mathrm{h} \mathrm{37}) & =235 \mathrm{~N} / \mathrm{mm}^{2} \\
\text { Shear Stress }(\tau \mathrm{g} \mathrm{37}) & =117,5 \mathrm{~N} / \mathrm{mm}^{2} \\
\text { Bending Stress }(\sigma \mathrm{l} 37) & =330 \mathrm{~N} / \mathrm{mm}^{2} \\
\text { Modulus of Elasticity }(\mathrm{E}) & =2 \times 105 \mathrm{~N} / \mathrm{mm}^{2}
\end{array}
$$

- Dimensions of the press box. In this design, the dimensions of the press box to be built are: $400 \mathrm{~mm} \times$ $400 \mathrm{~mm} \times 100 \mathrm{~mm}$. The weight of the $1 \mathrm{~mm}$ steel plate used according to the product catalogue is $7,9 \mathrm{~kg} / \mathrm{m} 2$ with a total weight as follows:

$$
\begin{aligned}
\text { Side Plate } & =400 \mathrm{~mm} \times 100 \mathrm{~mm} \\
& =0,4 \mathrm{~m} \times 0,1 \mathrm{~m} \\
& =0,04 \mathrm{~m} 2 \times 7,9 \mathrm{~kg} / \mathrm{m}^{2} \\
& =0,316 \mathrm{~kg} \times 4 \\
& =1,264 \mathrm{~kg}
\end{aligned}
$$

Since the side plates are all the same size, the result is multiplied by four

$$
\begin{aligned}
\text { Lower Plate } & =400 \mathrm{~mm} \times 400 \mathrm{~mm} \\
& =0,4 \mathrm{~m} \times 0,4 \mathrm{~m} \\
& =0,16 \mathrm{~m} 2 \times 7,9 \mathrm{~kg} / \mathrm{m}^{2} \\
& =1,264 \mathrm{~kg}
\end{aligned}
$$

The total weight of the press $=1,264 \mathrm{~kg}+1,264 \mathrm{~kg}=$ $2,528 \mathrm{~kg}$ 
- The moment of bending in the press box. Based on previous data, it is known that $\mathrm{Fp}=163,3 \mathrm{~N}$. It is assumed that the pressing force is evenly distributed along the press box $=400 \mathrm{~mm}$, then the assumption of the amount of moment occurs $(\mathrm{Wp})$ is:

$$
\begin{aligned}
W_{p} & =\frac{F p}{W b} \\
W_{p} & =\frac{163,3}{400}=0,4 \mathrm{~N}
\end{aligned}
$$

It is assumed that the weld joint is used to join the parts of the press box, then the amount of bending moment that occurs (Mlb) is:

$$
\begin{aligned}
& M_{\mathrm{ib}}=-\frac{W p \times W b x \times W b}{12} \\
& M_{\mathrm{ib}}=-\frac{0,4 \times 400 \times 400}{12}=-5333 \mathrm{~N} . \mathrm{mm}
\end{aligned}
$$

- Thickness of pressing holding plate. It is known that $\sigma 137=330 \mathrm{~N} / \mathrm{mm}^{2}$ and Mlb $5333 \mathrm{~N} . \mathrm{mm}$ so that the modulus of the sections allowed $(\mathrm{Z})$ is:

$$
\begin{aligned}
& Z=\frac{M_{l b}}{\sigma l 37} \\
& Z=\frac{5333}{330}=16 \mathrm{~mm}^{2}
\end{aligned}
$$

It is assumed that the cross section of the press box is rectangular with a length of $1 \mathrm{~b}=400 \mathrm{~mm}$. Based on this explanation, using the equation, the minimum thickness of the press box can be calculated, namely:

$$
\begin{aligned}
& t_{b} \geq \sqrt{\frac{Z \times 6}{l b}} \\
& t_{b} \geq \sqrt{\frac{16 \times 6}{400}}=0,5 \mathrm{~mm}
\end{aligned}
$$

- Calculation of welded joints on the press box. The welding process that is planned for the press box uses fillet welding. If the electrode used is E60 with tensile strength $(\sigma \mathrm{te})=62 \mathrm{kpsi}$ or $427.49 \mathrm{MPa}$, then the allowable shear stress ( $\tau \mathrm{ge})$ is:

$$
\begin{aligned}
& \tau \text { ge }=0,8 \times \text { ote } \\
& \tau \text { ge }=0,8 \times 427,49=341,99 \mathrm{MPa}
\end{aligned}
$$

And if it is known that $\tau$ ge $=341.99 \mathrm{Mpa}$ and Fp $=$ 163.3 $\mathrm{N}$ and the welding process is carried out along the height of the press box $=100 \mathrm{~mm}$, then the weld neck height (hl) is:

$$
\begin{aligned}
& h_{1} \geq \frac{F p}{\operatorname{tgl} x 0,707 \times h b} \\
& h_{1} \geq \frac{163.3}{341,99 \times 0,707 \times 100}=0,007 \mathrm{~mm}
\end{aligned}
$$

\section{3) Press plate calculation:}

- The bending moment on the press plate Based on previous data, it is known that $\mathrm{Fp}=163.3 \mathrm{~N}$ and the size of the press box is $400 \mathrm{~mm} \times 400 \mathrm{~mm} \times 100 \mathrm{~m}$. Then the length of the pressing plate and the planned width of the pressing plate is $400 \mathrm{~mm} \times 400 \mathrm{~mm}$. From the two data, the magnitude of the moment that occurs is:

$$
\begin{aligned}
& M_{\text {ip }}=\frac{F p \times l p}{4} \\
& M_{\text {ip }}=\frac{163,3 \times 400}{4}=16330 \mathrm{~N}=16,33 \mathrm{~N}
\end{aligned}
$$

- Pressing Plate Thickness. It is known that: $\sigma 137=330$ $\mathrm{N} / \mathrm{mm}^{2}$ and $\mathrm{Mlp}=20.6 \mathrm{KN}$. Based on these data the allowable cross-sectional modulus $(\mathrm{Z})$ is:

$$
\begin{aligned}
& Z=\frac{M l p}{\sigma l 37}= \\
& Z=\frac{16,33}{330}=0,05 \mathrm{~mm}^{2}
\end{aligned}
$$

It is planned that the cross-section of the pressing plate will be rectangular with a plate length (lp) of $400 \mathrm{~mm}$. so that with the following equation the permissible plate thickness is:

$$
\begin{aligned}
& t_{p} \geq \sqrt{\frac{Z \times 6}{l p}} \\
& t_{p} \geq \sqrt{\frac{0,05 \times 6}{400}}=0,03 \mathrm{~mm}
\end{aligned}
$$

4) Cylinder retaining frame design: In this cylinder retaining frame it is planned to. have a thickness of $2 \mathrm{~mm}$ using a ST 37 steel plate, while the weight of the steel plate has a size of $1 \mathrm{~mm}$ which is used according to the catalog on the product is $7.9 \mathrm{~kg} / \mathrm{m}^{2}$ with a total weight as follows:

$$
\begin{aligned}
\text { - Side } & =150 \mathrm{~mm} \times 100 \mathrm{~mm} \times 2 \\
& =30000 \mathrm{~mm} 2=0,3 \mathrm{~m}^{2} \\
& =0,3 \mathrm{~m}^{2} \times 7,9 \mathrm{~kg} / \mathrm{m}^{2} \\
& =2,37 \mathrm{~kg} \\
\text { - Front } \quad & =500 \mathrm{~mm} \times 50 \mathrm{~mm} \times 2 \\
& =0,5 \mathrm{~mm} \\
& =50000 \mathrm{~mm}^{2} \\
& =0,5 \mathrm{~m}^{2} \\
& =0,5 \mathrm{~m}^{2} \times 7,9 \mathrm{~kg} / \mathrm{m}^{2} \\
& =3,950 \mathrm{~kg}
\end{aligned}
$$


- Top Frame

$$
\begin{aligned}
& =500 \mathrm{~mm} \times 50 \mathrm{~mm} \\
& =25000 \mathrm{~mm} 2 \\
& =0,25 \mathrm{~m} 2 \\
& =0,25 \mathrm{~m} 2 \times 7,9 \mathrm{~kg} / \mathrm{m} 2 \\
& =1,975 \mathrm{~kg} \\
& =8,295 \mathrm{~kg}
\end{aligned}
$$

- Total weight

5) Pneumatic component planning:

- Press cylinder diameter. Based on previous data, it is known that $\mathrm{Fp}=163,3 \mathrm{~N}$ and if the working pressure used is $0.6 \mathrm{~N} / \mathrm{mm} 2$, then the diameter of the pressing cylinder is:

$$
\begin{aligned}
& D_{a b}=\sqrt{\frac{F p}{\frac{\pi}{4} \times P e}} \\
& D_{a b}=\sqrt{\frac{163,3}{0,785 \times 0,6}}=18,6 \mathrm{~mm} \approx 32 \mathrm{~mm} \\
& \mathrm{ds}=12 \mathrm{~mm}
\end{aligned}
$$

So, in this design a cylinder with the following specifications is used:

$\begin{array}{ll}\text { Product name } & \text { : Air Cylinder Pneumatik R-TEC } \\ \text { Model } & : \text { SC } 32 \times 150 \\ \text { Type } & : \text { DAC } \\ \text { Diameter } & : 150 \mathrm{~mm} \\ \text { Bore } & : 32 \mathrm{~mm} \\ \text { Rod diameter } & : 12 \mathrm{~mm} \\ \text { Proof pressure } & : 13.5 \mathrm{bar} \\ \text { Piston speed } \quad: 50-800 \mathrm{~mm} / \mathrm{s} \\ \text { Material : Aluminium } \\ \text { Cylinder stroke length }\end{array}$

○ Initial heigh $=$ press box height $+50 \%$ press box height $=100 \mathrm{~mm}+50 \mathrm{~mm}=$ $150 \mathrm{~mm}$

$\circ$ Final height $\quad=150 \mathrm{~mm}-70 \mathrm{~mm}=80 \mathrm{~mm}$

○ Minimum length $=150-30 \mathrm{~mm}=120 \mathrm{~mm}$

- Air required

Step out:

$$
\begin{aligned}
& Q_{0}=\frac{\pi}{4} \times D_{a b}^{2} \times S_{a b} \times n \times \frac{(P e+P a)}{P a} \\
& Q_{0}=\frac{\pi}{4} \times 20^{2} \times 200 \times 1 \times \frac{(0,6+0,1013)}{0,1013} \\
& Q_{0}=668137 \mathrm{~mm}^{3} / \mathrm{min} \\
& Q_{0}=0,67 \mathrm{lt} / \mathrm{min}
\end{aligned}
$$

Step in:

$$
\begin{aligned}
& Q_{i}=\frac{\pi}{4} \times\left(D_{a b}^{2}-d_{a b}^{2}\right) \times S_{a b} \times n \times \frac{(P e+P a)}{P a} \\
& Q_{i}=\frac{\pi}{4} \times\left(32^{2}-12^{2}\right) \times 120 \times 1 \times \frac{(0,6+0,1013)}{0,1013} \\
& Q_{i}=574,180 \mathrm{~mm}^{3} / \mathrm{mm} \\
& Q_{i}=0,57 \mathrm{lt} / \mathrm{mm}
\end{aligned}
$$

Total air required: It is known that Qo $=0.67$ litter $/$ minute and Qi $=0.57$ litter / minute. Based on these two data, the total air required by the pressing cylinder in one pressing cycle is:

$$
\begin{aligned}
\text { Qsb } & =\mathrm{Qo}+\mathrm{Qi} \\
& =1,24 \mathrm{lt} / \mathrm{min}
\end{aligned}
$$

6) Frame planning:

- Calculation of the load on the cylinder retaining frame (Fsp)

Mass of pressing cylinder $=0,65 \mathrm{~kg}$

The mass of the cylinder fixing bolt $=0,1 \times 12=1,2 \mathrm{~kg}$

Weight of cylinder holder frame $=8,295 \mathrm{~kg}$

$\mathrm{F}$ tofu $=163,3 \mathrm{~N}$

Press plate $=0,8 \mathrm{~kg}$

Fsp $=0,65+1,2+8,295+163,3 \mathrm{~N}+0,8=10,945 \mathrm{~kg}+$ $163,3 \mathrm{~N}=107,26 \mathrm{~N}+163,3=270,56 \mathrm{~N}$

- Calculation of the support frame Press Box (Fpb)

Fsp $=270,56 \mathrm{~N}$

Press box $=3,017 \mathrm{~kg}=29,57 \mathrm{~N}$

Weight tofu $=4,43 \mathrm{~kg}=43,4 \mathrm{~N}$

$\mathrm{Fpb}=270,56+29,57+44,3=343,53 \mathrm{~N} \approx 344 \mathrm{~N}$

- Calculation of frame legs

Total $\mathrm{F}=344 \mathrm{~N}=35.1 \mathrm{~kg}$

$\mathrm{L}$ plan $=730 \mathrm{~mm}$

$$
\begin{aligned}
& P C r=\frac{\pi^{2} \cdot E I}{L e^{2}} \Rightarrow L e=\sqrt{\frac{\pi^{2} \cdot E I}{P C r}} \\
& I=\frac{\pi}{64} \times d^{4} \\
& I=\frac{\pi}{64} \times(19,05 \mathrm{~mm})^{4}=6.464,7 \mathrm{~mm}^{4} \\
& L_{e}=\sqrt{\frac{\pi^{2} \cdot E I}{P_{C r}}} \\
& L_{e}=\sqrt{\frac{\pi^{2} \cdot\left(2,1 \times 10^{4}\right) \cdot\left(6,4647 \mathrm{~mm}^{2}\right)}{35,1 \mathrm{~kg}}} \\
& L_{e}=19.534,9 \mathrm{~mm}^{2}
\end{aligned}
$$

The planned frame leg length is $730 \mathrm{~mm}$. The buckling calculation shows that the maximum allowable length is 
$19,534.9 \mathrm{~mm}^{2}$. Since $\mathrm{L}<\mathrm{Le}$, the planned power thread length is SAFE.

\section{CONCLUSION}

Tofu pressing tool with Time Delay Valve Pneuatic System design is needed to be implemented because this machine has a lot of advantages. Based on the calculation, it is not spending so much time to produce the tofu which is 20 cycle/hour. In addition, using this machine is much cleaner than the traditional method. This design has great potential to be realized as a product and will be useful in the future.

\section{REFERENCES}

[1] H. Habibi, PERAN KOPERASI DALAM MENINGKATKAN PARTISIPASI ANGGOTA (Studi Kasus pada Koperasi Produsen Tahu dan Tempe Indonesia Kota Bandung Provinsi Jawa Barat), Doctoral dissertation, Institut Manajemen Koperasi Indonesia, 2019.
[2] P. Asih, "Metode Pengepresan Untuk Meningkatkan Kualitas Industri Pembuatan Tahu Di Kelurahan Kekalik Jaya Kota Mataram," Jurnal Abdi Mas TPB, vol. 2, no. 1, pp. 43-51, 2020.

[3] S. Simanungkalit and P.I. Sari, "Analisis Pemanfaatan Limbah Tahu dalam Meningkatkan Pendapatan Pengrajin pada UMKM Tahu (Studi Kasus Pada Pengrajin Tahu di Kecamatan Sungai Bahar Kabupaten Muaro Jambi)," SJEE: Scientific Journals of Economic Education, vol. 3, no. 2, pp. 47-56, 2019.

[4] T.O. Putri, Pengaruh Perbedaan Konsentrasi Terhadap Kinerja Plate and Frame Filter Press Pada Filtrasi Ampas Tahu (The Effect of Concentration Differences on the Plate and Frame Filter Press Performance on Tofu Pulp Filtration), Doctoral dissertation, undip vokasi, 2019.

[5] F. Fadillah, A.W. Rahmawan, A. Sanusi, A.S.F. Narariya, and R.I Andina, "Designing an automatic tofu pressing and molding machine for home industry," In 2017 5th International Conference on Electrical, Electronics and Information Engineering (ICEEIE), pp. 15-20, 2017.

[6] J.S. Arora, Optimum Design with Excel Solver. Introduction to Optimum Design, pp. 213-273, 2012. 